\title{
RE-WRITING OLD TESTAMENT LEGENDS IN LA QUESTE DEL SAINT GRAAL
}

\begin{abstract}
In this paper, I intend to present the way in which the Biblical stories and medieval legends are re-written in the episode of the Miraculous Ship in La Queste del Saint Graal, and to identify several characteristics of this vessel, considered ideal for the questers' preparation for the ecstatic life in the presence of the Grail. The multi-layered symbolism of this miraculous self-moving ship is constantly enriched with new connotations, and from being a sacred place that offers the successful knights the opportunity to meditate on their spiritual life before reaching Sarras and the Holy Grail, it may also be regarded as a connector between the Old-Testament legends, Christian traditions and Arthurian lore. In addition, the focus of the story shifts from Arthurian adventures to the creation of a story of origin and Galahad is presented not only as the quintessential Arthurian knight, but also the rightful heir of mythical ancestors. More importantly, analysing the way in which some medieval texts are recycled in this fragment, the reader is astonished to find a very progressive re-writing of the well-known literary tradition, as it reveals a very appreciative portrayal of women's agency and a tolerant attitude towards Jews (represented by Solomon). Both these aspects differ not only from the biblical perspective or dogmatic theories, but also from other $13^{\text {th }}$-century legends. Moreover, this inclusive approach to non-Christians is unique in the economy of La Queste.
\end{abstract}

Keywords: Biblical inspiration; Arthurian legends; Medieval Feminism.

La Queste del Saint Graal, the thirteenth-century text which is the penultimate part of the 'Lancelot-Grail' Cycle, abounds in dreams and visions with numerous connotations and hidden meanings, which enhance its mystical overtones. One of the most cryptic episodes is the voyage on the miraculous ship built by Solomon's wife, and this fragment, which interrupts the narration of ordinary chivalrous adventures, ascertains the mythical dimension of La Queste.

* University of Bucharest; Romania. 
The sources of inspiration for this episode are complex, as there were several medieval legends which could have been used as a starting point for the narrative, besides the Old Testament.

This episode actually consists of three parts: at first Galahad, Perceval and Bors are brought by Perceval's unnamed sister to a boat which brings them to this marvellous ship, built during Solomon's time by his wife, where they find a lot of threats against the impure and other writings, some of them being predictions which have already been fulfilled. When the ship and the richly decorated objects they find on board are described, the emphasis is placed on a bed with a canopy (or baldachin) with three wooden bedposts of different colours and on the sword placed on this bed. The second part tells the story of the construction of the ship, which starts with the legend of Eve and how the branch she carried with her when she left Eden turned into a tree, which changed its colour twice and whose wood was used to carve the bedposts. And the third time the ship is mentioned, it carries the successful Grail knights to Sarras, where they experience daily the spiritual power of the Holy Grail. ${ }^{101}$

\section{The ship as the Church}

The most obvious, and yet deceptive, interpretation of this Miraculous Ship is that of an allegorical image of "the Christian Church". There is an extensive bibliography talking about the Church as the ship that carries Christians towards salvation over the troubled waters of life. ${ }^{102}$ However, I believe that the Grail ship is not a metaphorical representation of the Church, first and foremost because, as I have already said, it prohibits the entrance of those who are not completely pure, which is contrary to the definition of the Church, considered to be the place where the sinful are purified. And secondly, because nothing is heard of it once the questers reach Sarras, so its meaning is limited and strictly related to Galahad and the Grail, and its declared purpose is to convey a message to Galahad, more precisely, as it is later revealed, a message from Solomon, his forebear.

\footnotetext{
${ }^{101}$ I want to add the fact that the importance of this episode is recognized by the medieval copyists and illustrators as there are depictions meant to highlight the Marvellous Ship, in most of the illuminated manuscripts of La Queste (for instance BNF Français 343, BNF Français MS 116, Royal MS 14 EIII, Yale MS 229, etc).

102 This symbolism was used from the first Christian centuries, all through the Middle Ages, to the present times and the central part of the church in between the narthex and the choir (or altar) is called "the nave", which comes from the Latin navis (i.e. ship).
} 
At the same time, there are common elements with the Celtic tradition of Irish monks searching God in their, sometimes oarless, boats, and trusting divine providence to guide them during their voyage (Lehane 73 ). In these instances the people on board of the vessel are not in control of it, and one such example could be the voyage undertaken by Saint Bredan and his monks. So, both the Grail Ship and the Celtic monks' ships were directly guided by God, and equally the miraculous ship and the boat used by Brendan (and Celtic Christians, in general) were carefully designed. However, these Celtic boats in themselves were ordinary, with no inherent significance and this is not the case in La Queste, as the Grail vessel is sacred and unique. It was conceived during an ancient Hebrew golden age and has haunted the seas until it reaches Galahad, the epitome of the perfect Christian knight and its intended beneficiary, so the Celtic influence cannot account for the deep allegorical significance of the ship as a connector of traditions.

In her work about The Quest of Seth, Solomon's Ship and The Grail, Esther Casier Quinn says:

The great ship in the Queste is more important than has hitherto been recognized. It is a perfect image into which diverse traditions have been drawn: it is the Temple, sent over the waters of time to merge with the Church; the Church conceived as spirit, as mobile as the waters on which it moved from Old Testament into Arthurian times ${ }^{103} \ldots$ the ship is an extraordinarily suitable device for linking ages, worlds, and ideas (216).

One final comment which has been made is that the Vulgate cycle can be regarded as a symbolical adaptation of the Bible, with the Prose-Lancelot as a foundational text, creating the background for the individual adventures, where the arrival of a Messiah (Galaad) is prophesised, just like an Old Testament. The fulfilment of these prophecies can be witnessed in La Queste, which can be regarded as a version of the Gospels and then an apocalypse (namely the end of

103 She continues by saying: "In the episode of the Solomon's ship, the account of the wood is subordinated to the Grail quest. [...] Although the spindles remain, the link between the Old and New Testaments is no longer the wood, but the ship" (Quinn, 217). I want to mention the fact that Esther Casier Quinn's essay was the starting point of this article. However, more than 50 years have passed since she wrote the article so naturally we interpret the sources differently, and my conclusions are totally different from hers. 
the Arthurian world) in Mort Artu, not without a final Redemption in its last pages (Valette 8). The Bible as a model for the Vulgate Cycle may seem rather farfetched; however, it is known that the biblical pattern has always been considered a point of reference and has been consciously or unconsciously followed by many works of fiction, especially in medieval times, so such associations are not unconceivable. If such an interpretation is taken into consideration, the importance of La Queste in the economy of the Cycle is enhanced.

Thus, although the Miraculous Ship does not symbolise the Church, as it was built during Solomon's reign and it was dedicated to Galahad, it can be said that it brings together the Old Testament stories and visions with the Christian tradition of the New Testament. So, perhaps the first level of interpretation of the ship is a means of showing that the old religious lore of the Jewish Temple can lead to the Christian one, and thus Solomon, the wise king of the Old Testament, can be regarded as an important character who prepares the way for the Coming of Christ, and also beyond, for the revelation of Galahad. I believe it is appropriate to point out that, for $13^{\text {th }}$-century audiences, the Adventures of the Grail were believed to have occurred roughly eight hundred years before their time, as the text mentions that when Galahad arrived at King Arthur's court " 450 years have passed since the passion of our lord Jesus Christ" (The Quest 33; La Queste 4). So Galahad was perceived, by the medieval readers of La Queste, as being part of their mythical and mystical past (just like King Solomon).

\section{The Old Testament as a Source of Inspiration}

In the Old Testament, Solomon is the epitome of wisdom, wealth and prosperity, ruling over a united kingdom and receiving the homage of foreign rulers like the Queen of Sheba (who is not mentioned in La Queste, but is a character that appears in some medieval legends that probably influenced it). Moreover, Solomon's wife's idea of constructing the Grail ship is connected with his role as the builder of the First Temple in Jerusalem. Digging a bit more in the Old Testament story of Solomon (found in the biblical historical book 1 Kings 2:12 - 11:43), one can see that despite his wisdom, he is portrayed as a man who makes mistakes, especially because of his many wives, none of which being described as intelligent, but rather devious. However, the Grail story insists (in a rather original way) that it is Solomon's wife the one who designs the ship, with the specific intention of fulfilling Solomon's desire to create a connection with 
"the knight" who would be "the ending of his line". Even more, although Solomon is the one to provide the sword which is placed on the bed, he fashions it according to his wife's instructions.

Despite the fact that she is considered by Solomon to have a great amount of 'engin', translated as 'cunning', cheating or trickery, she describes herself as having 'subtilité', translated as 'ingenuity' (La Queste 220, 222; The Quest 230-1). The author knows and quotes the medieval theory about the innate deceitfulness of women, but this notion is rendered as being Solomon's perspective. His negative opinion on women is highlighted by a quotation from Ecclesiastes 7, 2728 , but there is no other mention of this book of the Old Testament. ${ }^{104}$ Eventually, her artfulness is positively used, and thus one can witness, in this instance, a reversal of the traditional negative perception of women in decision-making positions.

Another important biblical text which is attributed to Solomon and is woven into this episode is the biblical Song of Solomon (Song of Songs, or Canticle of Canticles), which is a celebration of the mystical encounter with God, manifested through love. One of the most important emotions that characterises The Song of Solomon is the joyful feeling of anticipation, because of the imminent arrival of the beloved. This cheerful excitement resonates with the people's expectations in La Queste, and thus, there is deep optimism and relentless hope in both the Song of Solomon's lyricism and in La Queste's predictions uttered by various holy hermits, priests or nuns. In addition, this Book is one of the very few instances in the Old Testament when the relationship with God is achieved through love, and not fear. Several details may point out to the fact that this Old-Testament book was known to the author of La Queste and one example is the importance given to the description of the bed on the Miraculous ship (where great emphasis is placed on the baldachin and the bedposts) which can be associated with the depiction of Solomon's bed from the following fragment from the third chapter of The Song:

Behold his bed, which is Solomon's; [...]. King Solomon made himself a palanquin [that is a litter or a moving bed] of the wood of Lebanon. He made the pillars [the bedposts] thereof of silver, the bottom thereof of gold, the

\footnotetext{
${ }^{104}$ When Solomon complains about women's innate pleasure in annoying men, a celestial voice reveals to him that a woman, who will be his descendent, will bring joy to mankind, a clear reference to the Virgin Mary. (La Queste 221, The Quest 230).
} 
University of Bucharest Review $\propto$ Vol.X/2020, no. 2 (new series)

Re-writing, Re-imagining the Past (II)

covering of it of purple, the midst thereof being paved with love, for the daughters of Jerusalem (Song of Songs 3:7-10)

Naturally, the image of the bed is present several times in The Song, and it may account for another literal meaning of the Miraculous ship, namely the carrier of a material object (the bed), which makes possible the strong connection between man (represented by Galahad) and God. The bed becomes, in this instance, an allegory of the cross (on which Galahad lies and sleeps) or rather Galahad lying on the bed becomes the image of Jesus Christ hanging (rather than lying) on the cross. The association between Galahad and Christ is openly mentioned in the text several times, for instance when Galahad casts out a demon from a tomb at the beginning of his adventures (La Queste 36, The Quest 62) and also when he performs a healing the moment he steps out of the miraculous ship, just before he enters Sarras at the ending of his voyage (La Queste 275, The Quest 281).

It is important to point out that the episode narrating the story of the ship differs significantly from the rest of $L a$ Queste in regards to the attitude towards the Jews, and more specifically in the way Solomon and his wife are portrayed. There are many instances in La Queste when there is a visible intention "to promulgate and encourage anti-semitism by presenting the adherents of the 'Old

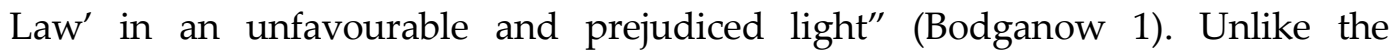
instances (in other parts of La Queste) when a clear comparison between the Old (Judaic) Law and the New Christian one is made, pointing out the latter's superiority, the history of the construction of the Grail ship portrays Solomon's times as a golden age, foretelling and even preparing the Christian one.

The Miraculous ship is older than Christianity and thus it projects Galahad, who is the addressee, not only in Solomon's epoch of wisdom and prosperity, but also into the mythical time of creation; since, by listening to the story of how the bed (and its bedposts) came into being, he becomes a witness to the Fall from grace and to the events that followed it. The Old Testament inspiration for the Miraculous Ship episode in La Queste is not only direct, but also mediated by medieval legends that complete the story of Adam and Eve and create a connection between them and Christian salvation.

\section{Insights into The Legend of the Tree of Life}

The medieval "Legend of the True Cross", which can be found in various 
texts and versions (and one such example is recorded in the $13^{\text {th }}$-century Jacobus de Voragine's Legenda Aurea or the Golden Legend ${ }^{105}$ ), can be also considered a direct influence for Solomon's ship episode. This legend and the narrative "Legend of the tree of life" in La Queste unite in one story: Adam and Eve's sin, the Jewish tradition (encapsulated in Solomon's interaction with the Queen of Sheba) and Christian salvation.

Briefly, the legend states how Adam, on his deathbed, sends his son Seth to the Archangel Michael, to give him some oil of mercy to be healed, but Seth only receives a shoot or a seedling (or three seeds) from the tree of the original sin, and he plants it (or them) on his father's grave (at his head, in his mouth, etc). Actually, an allegorical connection can be made between Galahad and Seth, as Galahad is also asked (and even manages) to heal the Maimed King, who awaits his arrival.

A tree grew on Adam's grave and the cross of Christ's passion would be fashioned from it, although it had been chopped down by Solomon, who wanted, but was unable to, use it for his Temple. In this legend, Solomon is told (by the Queen of Sheba) that Christ's sacrifice will bring about the ending of the Kingdom of the Jews, so he hides the wood of the cross, to prevent it from happening.

The first essential difference between Voragine's legend (and indeed all versions of this legend) and the chapter "Legend of the Tree of Life" in La Queste, is the presence of Eve, as the one who carries the twig from the tree of the 'forbidden' or 'deadly' fruit out of Paradise (La Queste 210, The Quest 222) and who plants it (while Seth is not even mentioned). Actually, this change is explained dogmatically, as "the bearing of the branch pertained not to the man, but to the woman [...] it signified that through a woman life was lost, and through a woman life would be regained" (The Quest 224). ${ }^{106}$ The theological explanation demonstrates that female agency is not only essential, but also

\footnotetext{
${ }^{105}$ Jacobus de Voragine's "Legend of the True Cross", (277-8) is also presented in the medieval Cornish play, Gwreans an Bys (Origo Mundi, the first play of the late fourteenth-century Cornish Ordinalia, meaning The Origin of the World, also known as Ordinale de Origine Mundi, 2,846 lines, written in middle Cornish. (Daisy Black, "The Time of the Tree: Returning to Eden after the Fall in the Cornish 'Creacion of the World'"). Actually, various versions are summarised by Marinus Jonge and Johannes Tromp in their work "The Life of Adam and Eve" and related literature". 106 “Li porters dou rainsel n'apartenoit pas a l'ome se a la fame [...] senefioit il que par fame estoit vie perdue et par fame seroit restore" (La Queste 213).
} 
justifiably so.

The next important difference is the presence of Solomon's wife, a character who replaces the Queen of Sheba and who acts as both wise adviser and bold constructor. She continues Eve's work and her success is complete when Perceval's sister explains the history of the ship. The association between these three women: Eve, the nameless wife of Solomon and Perceval's sister, emphasise the continuation between the time of the Holy Grail and the primordial time, the time of the unspoiled creation of man and woman, before the ancestral Fall.

Furthermore, the tree itself is miraculous and participates in the first humans' lives, as it changes its colour, becoming green when Eve becomes pregnant (although shoots taken from it before and planted in the ground by both Adam and Eve retained their original white hue). There are also green shoots from this transitional tree that remain green, even though the first tree changes its colour again and becomes red when Abel is killed.

In the version of the legend that appears in La Queste, Solomon's destructive attitude towards the wood of the cross and Jesus Christ is replaced by devout worship and by the desire to be connected with the last of his descendants, the good (Christian) knight Galahad. Moreover, Solomon's wife is divinely inspired to build a ship which carries remnants of the Garden of Eden, because the bed has three bedposts each made from a tree with one of the three colours (white, green and red) making it an elusive representation of Garden of Eden. Thus, the image of the cross on which Christ will suffer being fashioned from the tree brought from the Garden of Eden was replaced in La Queste with the creation of the ship and its bed with the tree colourful bedposts. The ship is, hence, a replica of the Garden of Eden, which only the pure can enter, and the bed is associated with the cross.

Since the legend of the Holy Cross (shaped from a tree growing on Adam's grave) was common knowledge for La Queste audience, it comes without saying that the connection cross-bed was visible. In addition, there is a continuation between Galahad's actions at the beginning of La Queste, in Camelot (when he draws the sword from the red stone, after others had failed, and then sits down in the Perilous Seat) and at the ending of his voyage, on the ship (when he draws the sword from the red scabbard and lies on the bed, assuming thus the position of crucified Christ and re-enacting Christ's death on the cross). Formerly it was assumed that the narrative climax of the Queste occurs at Corbenic, but in terms of religious allegory the climax is Galahad's return to Solomon's ship, where he 
places himself on the bed in a symbolic re-enactment of the crucifixion (Quinn, 222). Because of this movement he becomes the epitome of a Christian knight, while the ship is symbolically a higher and more spiritualised Camelot, as if the Arthurian tradition is further enriched by Christian symbolism.

In the Middle Ages when texts were commonly reused and originality was regarded with suspicion, it is to be expected that older stories were woven into new ones and quite often the old pattern is discernible. The choice of certain texts and the way they are adapted to the writers' perspective can play the role of some rudimentary criticism. "Criticism here is not separate from creation, but is rather built into the creative process" (Dinsaw 11). In La Queste the way these Old-Testament legends were adjusted draws attention on the importance of women's intervention, as these three women actually fashion the environment, since they build and explain the importance of the most sacred place in the text, and their presence cannot pass unnoticed.

In the Old Testament Solomon was the person who built the Jewish Temple, and also, in the medieval legend, he tried to oppose Jesus, by hiding the wood that would become the cross. In addition, Solomon of the Old Testament was famous not only for his wisdom, but also for his lapse from the right faith, when he worshiped false gods under the influence of his wife(ves), just like Adam took Eve's advice. This episode in La Queste rewrites the biblical story (and the medieval legend) completely and redeems Solomon, who is not an idolatrous persecutor of Christians (as any Jew was believed to be), but rather a person in search of the correct faith, in need of establishing a connection with Galahad, the most pure of the Christian knights (and, equally, a symbolic representation of Christ).

It is important to point out that appreciation for women playing a significant part in medieval society was not familiar to medieval audiences, who would rather insist on female subjection, as fated by God. "It is hard to fault the Middle Ages for lacking feminist theory when the[...] world medieval people knew, complete with hierarchy and patriarchy, was a world ordained by God" (LeGates 42). Thus, it is even more remarkable to see how in a work with a strong religious foundation these three women are positively presented although they assume a leading role and their actions make them stand out as they move beyond a woman's traditional role. Eve is the carrier of the seed of hope and replaces Seth, Solomon's wife supersedes her husband in ingenuity and her work is deeply spiritualised, while Perceval's sister becomes the Grail knights' guide. 
Contrary to any traditionally feminine subservient attitude, Solomon's wife assumes the instrumental role in the creation of the miraculous salvific ship, and she highlights Eve's involvement, by using the wood that sprung from her twig to fashion the wondrous bedposts. This cooperation is acknowledged by Perceval's saintly sister who presents the ancient, pre-Christian ship as a means of facilitating the mystical union between man and God, and thus endows it with Christian significance. Despite being nameless, like several other young maidens that prophesise Galahad's success, Perceval's sister is essential for the knights' progress, and she follows them even after her martyric death, as her saintly body floats in a divinely-propelled ship and is respectfully buried at Sarras.

\section{Conclusions}

When the sources of the episode of the Miraculous Ship are identified, one can witness a profound feminization of the original stories, where the main male characters are replaced by female ones: Seth (from the "Life of Adam and Eve") is replaced by his mother, Eve (who brings the twig and plants it) and Solomon, who, in the Old Testament, constructs the Temple, is surpassed by his wife, who becomes the inspired builder the ship. Their heritage is completed by Perceval's sister, who guides the three questers. There is, thus, an unexpected feminine transmission of mystical inheritance, and the unnamed sister of Percival is portrayed as the repository of ancient wisdom.

Another surprising element for medieval times, is the image of Solomon, the Jew, as accepting and even looking up to his Christian descendent (Galahad), yearning to be connected to him and thus, accepting Christian salvation, too. This perspective is quite contrary to the image portrayed by the $13^{\text {th }}$-century wellknown "Legend of the Cross". The Old Testament story is also re-fashioned, as, in La Queste, Solomon is not prey to his wife's (or I should say wives') idolatry, but rather his spiritual life is enriched by her actions, so despite his annoyance with her, they can collaborate harmoniously.

The voyage on the Miraculous Ship, more than other parts of La Queste, portrays an ideal environment for spiritual progress where the divine will is quite perceptible. It is this close connection with God which may account not only for the illuminating revelations received by the questers, but also for the uniquely positive presentation of Solomon (the king of the Jews) and of the dynamic knowledgeable women, who guide the men close to them towards a rewarding outcome. 


\section{Works Cited}

Re-writing, Re-imagining the Past (II)

***. La Queste del Saint Graal, ed. A. Pauphilet, Paris: Champion, 1923. (abbreviated as La Queste).

***. The Quest of the Holy Grail. London: Penguin Books, 1969. (abbreviated as The Quest).

Black Daisy "The Time of the Tree: Returning to Eden after the Fall in the Cornish Creacion of the World”, Medieval Feminist Forum, vol. 50 no. 1, 2014: 61-89 Web 29 May 2021

$<$ https://core.ac.uk/download/pdf/61174344.pdf >.

Bogdanow, Fanni. "The Grail Romances and the Old Law”. Arthurian Studies in Honour Of P.J.C. Field. Ed. Bonnie Wheeler. Cambridge: D. S. Brewer, 2004: 1-13. Print.

Burle-Errecade Élodie. "Dire et raconter dans La Queste del Saint Graal". Littératures 50, 2004. Tocqueville. Les Poètes de l'Amour. La Queste del Saint Graal. 191-210. Web 29 May 2021

$<$ https://www.persee.fr/doc/litts_0563-9751_2004_num_50_1_1929>.

Dinshaw, Carolyn. "Medieval feminist criticism”. A History of Feminist Literary Criticism. Ed. Gill Plain and Susan Sellers. Cambridge University Press, 2007: 11-26. Print.

Gilson Étienne. "La mystique de la grâce dans La Queste del Saint Graal”. Romania 51 (1925): 321-347. Print.

De Jonge Marinus, Johannes Tromp. The Life of Adam and Eve and Related Literature. Sheffield: Sheffield Academic Press, 1997.

LeGates, Marlene. In Their Time. A History of Feminism in Western Society, London: Routledge, 2001. Print.

Lehane, Brendan. Early Celtic Christianity. London: Continuum, 2005. Print.

Kennedy Elspeth. "The Making of the Lancelot-Grail Cycle". A Companion to the Lancelot-Grail Cycle. Ed Carol Dover. Cambridge: D.S. Brewer, 2003: 13-22. Print.

Matarasso, Pauline, The Redemption of Chivalry. A Study of the Queste del saint Graal, Genève: Librarie Droz, 1979. Print.

Quinn, Esther Casier. "The Quest of Seth, Solomon's Ship and The Grail." Traditio, vol. 21, Fordham University, 1965: 185-222. Web 10 May 2021 $<$ http://www.jstor.org/stable/27830792>.

Valette, Jean-René. " La Queste del Saint Graal, une hagiographie en semblance : défi laïque et spiritualité décléricalisée ». Les Dossiers du Grihl. 03 December 2015. Web 09 May 2021. 
University of Bucharest Review $\propto$ Vol.X/2020, no. 2 (new series)

Re-writing, Re-imagining the Past (II)

$<$ http://journals.openedition.org/dossiersgrihl/6324>.

Williams, Andrea M.L. The Adventures of the Holy Grail: A Study of La Queste del Saint Graal. Bern: Peter Lang, 2001. 